\title{
Letter to the Editor ESTABLISHMENT OF CELL LINES FROM THE PACIFIC OYSTER
}

Dear Editor:

In vitro cultures of marine mollusk cells have been developed by many investigators for studying the defense mechanisms or pathogens of mollusks $(1,4,11,19)$. Recently, increasing numbers of intracellular parasites, such as virus, rickettsias, chlamydias, and protozoa of Apicomplexa and Haplosporidia, have been discovered in marine bivalves, and some of them have been found to cause epizootic diseases $(12,21)$. Thus, there is an urgent need to establish cell lines from marine bivalves in order to investigate these pathogens.

Several attempts have been performed on the establishment of a marine molluscan permanent cell line from oysters, including Crassostrea virginica, Pinctada fucata, $P$. margaritifera, Ostrea edulis, and clams, Mercenaria mercenaria, Mya arenaria, and Spisula solidissima $(2,3,8,10,13,15,18,20,22,23,25)$. In a review of these reports, it was found that cultures from adult-tissues, such as heart and mantle, of marine mollusks were difficult to subcultivate successfully.

Attempts at establishing cell lines from the heart tissue of the Pacific oyster, Crassostrea gigas Thumberg, double strengthened Leibovitz L15 medium ( $2 \times$ L15) containing $20 \%$ fetal bovine serum (FBS, CSL), with pH adjusted to 7.2-7.4 and osmolarity at $720-740 \mathrm{mmol} / \mathrm{kg}$, was used as a basal medium. Several extracts and/or growth factors were added to the basal medium to compose various growth media (Table 1).

\section{TABLE}

\section{COMPOSITION OF GROWTH MEDIA}

\begin{tabular}{ll}
\hline Media $^{a}$ & \\
\hline 1 & $2 \times$ L15 $+20 \%$ FBS (basal medium) \\
2 & Medium $1+5 \%$ oyster gonad extract \\
3 & Medium $2+5 \%$ bovine pituitary gland extract \\
4 & Medium $2+5 \%$ Rabbit pituitary gland extract \\
5 & Medium $2+5 \%$ rat pituitary gland extract \\
6 & Medium $2+5 \%$ carp pituitary gland extract \\
7 & Medium $2+1 \%$ Nutridoma-SP \\
8 & Medium $2+1 \%$ Nutridoma-HU \\
9 & Medium $2+1 \%$ Nutridoma-NS \\
10 & Medium $2+2 \%$ Nutridoma-SP \\
11 & Medium $2+2 \%$ Nutridoma-HU \\
12 & Medium $2+2 \% \mathrm{Nutridoma-NS}$ \\
13 & Medium $2+50 \mathrm{ng} / \mathrm{ml} \mathrm{FGF}$ \\
14 & Medium $2+100 \mathrm{ng} / \mathrm{ml} \mathrm{FGF}$ \\
15 & Medium $2+50 \mathrm{ng} / \mathrm{ml}$ EGF \\
16 & Medium $2+100 \mathrm{ng} / \mathrm{ml} \mathrm{EGF}$ \\
17 & Medium $2+10 \mathrm{ng} / \mathrm{ml}$ insulin \\
18 & Medium $2+20 \mathrm{ng} / \mathrm{ml}$ insulin \\
19 & Medium $2+50 \mathrm{ng} / \mathrm{ml}$ insulin \\
\hline
\end{tabular}

${ }^{a}$ Osmolarities were adjusted to $720-740 \mathrm{mmol} / \mathrm{kg}$ and $\mathrm{pH}$ at $7.2-7.4$.
Twenty to 30 fragments, for heart explant culture, were inoculated into a T25-flask (Nunc). All heart explants underwent a similar initial series of events when cultured in various growth media. Cells migrated out from the heart explant and formed a cell sheet surrounding the explant within the first day. During the period from the 2 nd to the 7 th day after initiation, the hemocyte-like cell sheet extended further outwards and occupied most of the surface of the culture vessel (Fig. 1). Fibroblast- and epithelial-like cells also grew outwardly following the cultures progressed (Fig. 2). Confluent cell cultures were usually obtained within $7-10$ days, under optimum conditions. The results indicate media containing extract from oyster gonadal tissue significantly promoted cell proliferation. Extract of pituitary gland of rat, bovine, rabbit, or common carp were also shown to stimulate cell proliferation. However, growth factors such as FGF, EGF, Nutridoma products (BM), and insulin did not significantly stimulate cell multiplication. Cultures in which the medium was supplemented with $5 \%$ extracts of oyster gonad and pituitary gland, for example, were subcultivated 6 times. In these cultures, a population of epithelial-like cells proliferated significantly and after the lst subculture, the cells became a dominant cell type as shown in Fig. 3. Following subcultivation, tissue fragments became smaller and then disappeared.

Cells at second subculture level of heart explant culture were used to analyze chromosome numbers according to the method of Chen (5). The distribution of chromosomes, as shown in Fig. 4, indicates chromosome loss occurred in the cultures and the modal number was 20 .

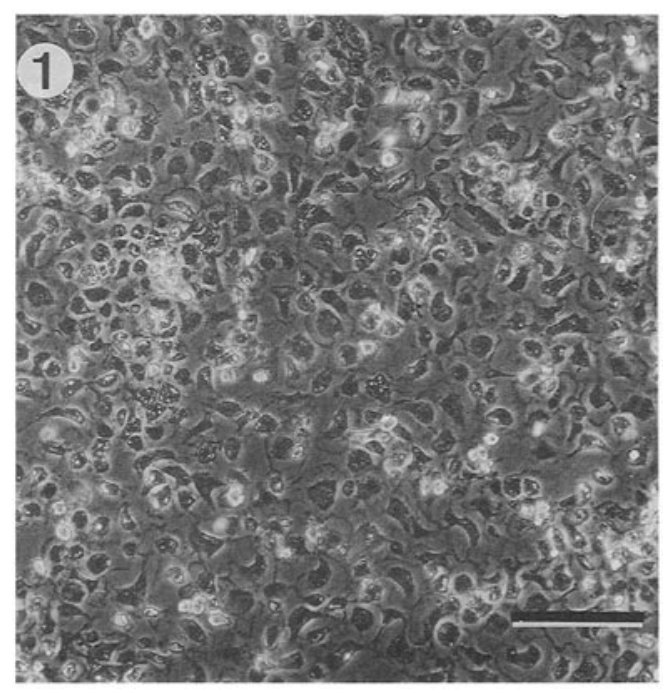

Fig. 1. Micrograph of a confluent monolayer of hemocyte-like cells obtained from oyster heart explants at Day 7 after initiation. The explants were cultured with medium 2. Bar $=100 \mu \mathrm{m}$. 


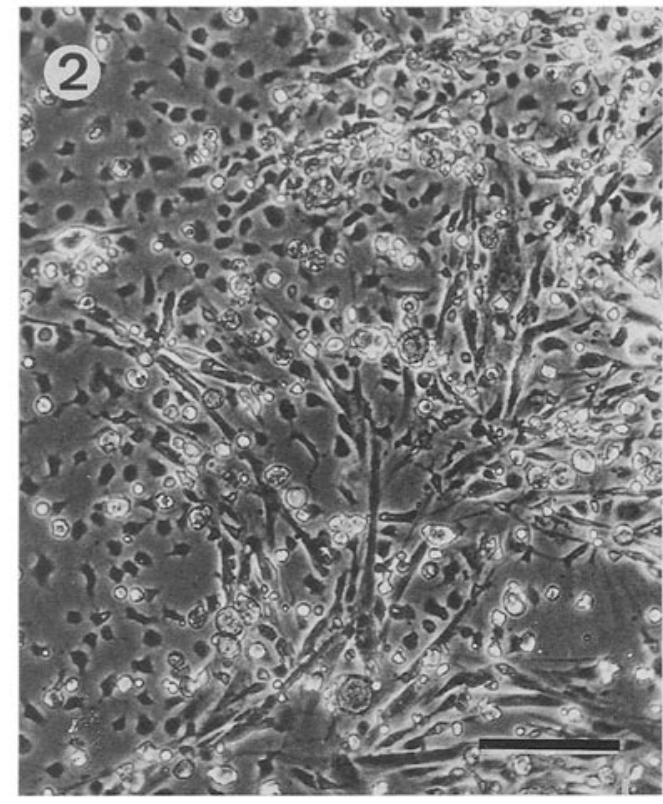

FIG. 2. Micrograph of a confluent monolayer of cells obtained from oyster heart explants at Day 7 after initiation. Spindle and epithelial-like cells are evident; some of the spindle cells are myocardiocytes. Explants were cultured in medium 3. Bar $=100 \mu \mathrm{m}$.

Cell cultures were initiated with enzymatically dissociated the fragmented heart tissues by enzyme solution of trypsin, collagenase or protease. In general, judged by the relative numbers of viable and adherent cells, the best results obtained from enzyme dissociation were those cultures established from treatment in solution of collagenase or protease. Populations of cell types revealed some differences between each kind of enzyme solution treatment. Heart

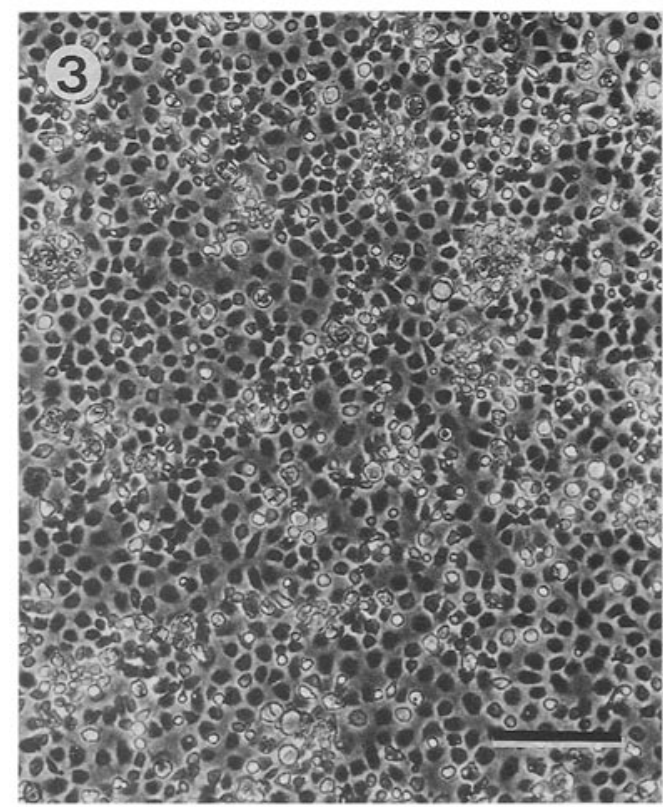

FIG. 3. A micrograph showing confluent monolayer of epithelial-like cells cultured with medium 3 . The cells proliferated significantly after the first subculture. $B a r=100 \mu \mathrm{m}$.

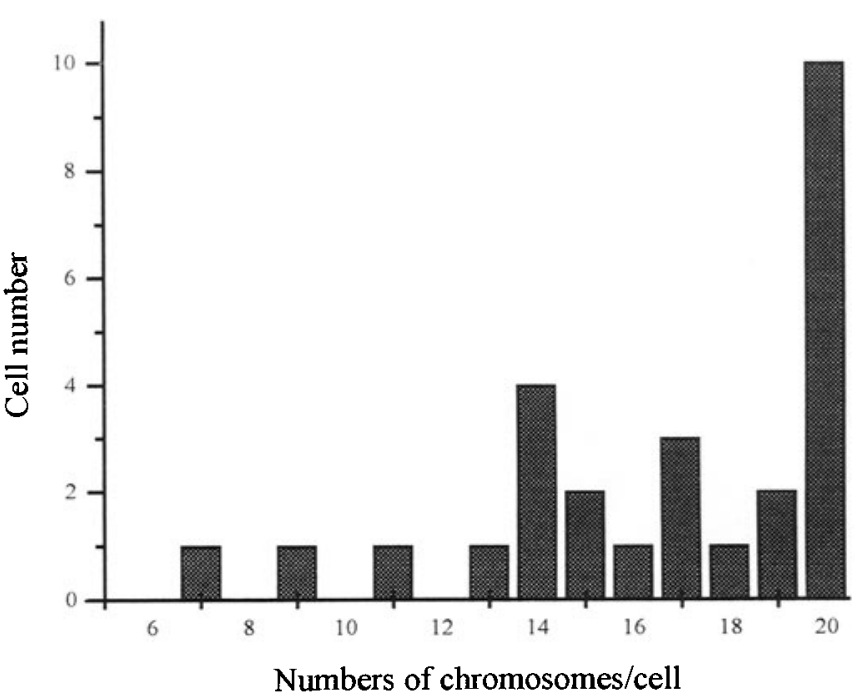

FIG. 4. Distribution of chromosome numbers of oyster cells in colcemid metaphase at the second level of subculture.

tissue treated with collagenase or protease yielded numerous fibroblast-like cells (including cardiomyocytes), epithelial-like cells, and granular hemocytes, which would adhere to the culture vessel (Fig. 5). Heart tissue treated with trypsin, however, had significant numbers of fibroblast cell and suspended spherical cells. Enzyme dissociated cultures could not be maintained for as long as explant cultures and usually could subcultivate only one time under the best conditions.

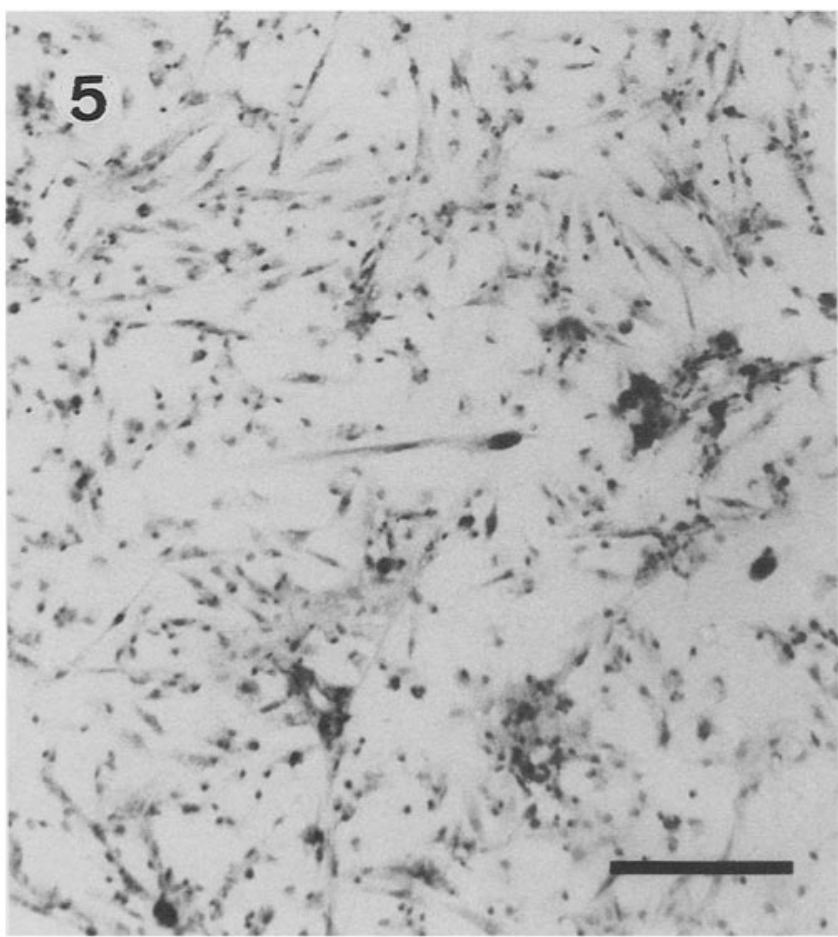

FIG. 5. A micrograph of oyster heart cells obtained by collagenase dissociation and stained by Wright's stain. The cells were cultured with medium 3. Bar $=100 \mu \mathrm{m}$ 
The L15 medium contained higher concentrations of amino acids than the other commercialized media, which may make it better for the in vitro culture of marine animals $(6,13)$. However, it contained no prolin and taurine which are common in the hemolyph of marine bivalves $(7,16,24,26)$. Prolin and taurine added to the medium to improve the nutrition was not more efficient (authors' unpublished results). These results are similar to previous studies $(9,13)$. A synthetic medium with components similar to those found in of the hemolymph of a marine bivalve may be useful for successful in vitro culture of marine bivalves (17). However, this is complicated by the fact that the concentrations of amino acids of hemolymph varied with environmental salinity and species $(16,24)$.

The results of this study indicate that, judging from number of culture periods and subcultures, explant cultures from oyster heart tissues were better than those cell cultures. It may be possible that the medium was conditioned by tissue fragments, and thus the explant culture was maintained longer than the cell culture (13). In this investigation, however, we have demonstrated a unique cell (epithelial-like) that proliferated significantly after the first passage of the heart explant cultures. Supplements of FBS, oyster gonad extract, and extract of bovine, carp, or rat are helpful for cell adherence and multiplication.

In summary, the in vitro culture systems described in this study is the first ever published paper describing the establishment of monolayer cultures up to 6-subculture level. The susceptibility of these cells against various virus of marine mollusk are undertaken and the results will be published elsewhere.

\section{ACKNOWLEDGEMENTS}

This study was supported by the National Science Council, Republic of China (NSC80-0209-B-002-02 and 81-0209-B002-06).

\section{ReFERENCES}

1. Boulo, V.; Hervio, D.; Morvan, A., et al. In vitro culture of mollusc hemocytes: functional study of burst respiratory activity and analysis of interactions with protozoan and procaryotic pathogens. In Vitro Cell. Dev. Biol. 26:42A; 1991. (Abstract)

2. Brewster, F.; Nicholson, B. L. In vitro maintenance of amoebocytes from the American oyster (Crassostrea virginica). J. Fish. Res. Board Can. 36:461-467; 1979.

3. Cecil, J. T. Mitoses in cell cultures from cardiac tissue of surf clam Spisula solidissima. J. Invert. Pathol. 14:407-410; 1969.

4. Chagot, D.; Boulo, D.; Hervio, D., et al. Interactions between Bonamia ostreae (Protozoa: Ascetospora) and hemocytes of Ostrea edulis and Crassostrea gigas (Mollusca: Bivalvia): entry mechanisms. J. Invert. Pathol. 59:241-249; 1992.

5. Chen, T. R. Fish chromosome preparation: air-dried displays of cultured ovarian cells in two killifishes (Fundulus). J. Fish. Res. Board Can. 27:158-161; 1970 .

6. Chen, S. N.; Chi, S. C.; Kou, G. H., et al. Cell culture from tissue of grass prawn, Penaeus monodon. Fish Pathol. 21:161-166; 1986.

7. Deane, E. D.; O'Brien, R. W. Composition of the haemolymph of Tridacna maxima (Mollusca: Bivalvia). Comp. Biochem. Physiol. 66A:339-341; 1979.

8. Ellis, L. L. Mitotic activity of oyster cell cultures supplement with embryo extract and liposomes. In Vitro Cell. Dev. Biol.. 23:39A; 1987. (Abstract)
9. Ellis, L. L.; Bishop, S. H. Isolation of cell lines with limited growth potential from marine bivalves. In: Mitsuhashi, J., ed. Invertebrate cell system application, vol. II. Boca Raton, Florida: CRC Press; 1989:243-251.

10. Ellis, L. L.; Brodey, M. M.; Bishop, S. H. Preparation of cells from oyster heart and mantle. In Vitro Cell. Dev. Biol. 21:32A; 1985. (Abstract)

11. Ford, S. E.; Alcox, K. A. In vitro interactions between molluscan hemocytes and the parasitic protozoan Haplosporidium nelsoni (MSX). In Vitro Cell. Dev. Biol. 29:82A; 1993. (Abstract)

12. Fries, C. R.; Grant, D. M. Rickettsiae in gill epithelial cells of the hard clam, Mercenaria mercenaria. J. Invert. Pathol. 57:166-171; 1991.

13. Hetrick, F. M.; Stephenes, E.; Lomax, N., et al. Attempts to develop a marine molluscan cell line. Maryland Sea Grant Program, Publ. No. Um-SG-TS-81-06, 88; 1981.

14. Laucker, G. Disease of mollusca: Bivalvia. In: Kinne, O., ed. Disease of marine animal, vol. II. Hamburg: Biologische Anstalt Helgland; 1983:479-489.

15. Li, M. F.; Stewart, J. E. In vitro cultivation of cells of the oyster, Crassostrea virginica. J. Fish. Res. Board Can. 23:595-599; 1966.

16. Lynch, M.; Wood, L. Effects of environmental salinity on free amino acids of Crassostrea virginica Gmelin. Comp. Biochem. Physiol. 19:783-790; 1966

17. Machii, A.; Wada, K. T. Some marine invertebrates tissue culture. In: Mitsuhashi, J., ed. Invertebrate cell system application, vol. II. Boca Raton, Florida: CRC Press; 1989:226-233.

18. Mialhe, E.; Boulo, V.; Grizel, H. Bivalve mollusc cell culture. Am. Fish. Soc. Sp. Publ. 18:311-315; 1988.

19. Mourton, C.; Boulo, V.; Chagot, D., et al. Interactions between Bonamia ostreae (Protozoa: Ascetospora) and hemocytes of Ostrea edulis and Crassostrea gigas (Mollusca: Bivalvia): in vitro system establishment. J. Invert. Pathol. 59:235-240; 1992.

20. Perkins, F. O.; Menzel, R. W. Maintenance of oyster cells in vitro. Nature 204:1106-1107; 1964.

21. Sindermann, C. J. Principal diseases of marine fish and shellfish, vol. 2. San Diego, New York, Boston, London, Sydney, Tokyo, Toronto: Academic Press; 1990:516.

22. Stephens, E. B.; Hetrick, F. M. Cultivation of granular amoebocytes from the American oyster. TCA Manual 5:991-992; 1979a.

23. Stephens, E. B.; Hetrick, F. M. Preparation of primary cell cultures from the American oyster, Crassostrea virginica. In Vitro Cell. Dev. Biol. 15:198; 1979b. (Abstract)

24. Suzuki, T.; Ogata, H.; Funakoshi, S., et al. Free amino acid composition in the hemolymph of marine and freshwater bivalves (Japanese with English abstract). Bull. Natl. Res. Inst. Aquaculture 1 1:27-34; 1987.

25. Tripp, M. R.; Bisignani, L. A.; Kenny, N. T. Oyster amoebocytes in vitro. J. Invert. Pathol. 8:137-140; 1966.

26. Yano, 1. Amino acid composition of the body fluids in Pinctada fucata and Crassostrea gigas (Japanese with English summary). Bull. Natl. Pearl Res. Lab. 22:2327-2321; 1977.

$\begin{aligned} & \text { Chiou-Ming Wen } \\ & \text { Guang-Hsiung Kou }\end{aligned}$


Department of Zoology
National Taiwan University
Taipei 106
Taiwan, Republic of China

(Received 13 July 1993)

\footnotetext{
${ }^{1}$ Present address: The Institute of Fishery Biology, Room 201, National Taiwan University, Taipei 106, Taiwan.
} 